\title{
Modułowe konstrukcje jedno- i dwukabinowych lokomotyw elektrycznych i spalinowych
}

\begin{abstract}
$W$ artykule zaprezentowano procesy zwiqzane z projektowaniem, budowa, badaniami $i$ wdrożeniami do eksploatacji nowych oraz modernizowanych lokomotyw elektrycznych $i$ spalinowych przeznaczonych do ruchu liniowego i prowadzenia prac manewrowych i przetokowych.

Zaprezentowano $w$ nim osiagnięcia krajów europejskich we wdrażaniu do ruchu platformy nowoczesnych lokomotyw liniowych oraz $w$ modulowej modernizacji lokomotyw spalinowych najczesściej jednokabinowych wykorzystywanych w pracach manewrowych. Ponadto przedstawione zostaty korzyści wynikajace $z$ wdrożenia do produkcji i eksploatacji modułów, które moga być wykorzystywane w wielu typach (seriach) lokomotyw, zarówno liniowych jak i manewrowych.

Artykut zawiera również rozwiazania modułowe zastosowane $w$ lokomotywach liniowych oraz propozycje modulów do zastosowania w jednokabinowych lokomotywach spalinowych przeznaczonych do prac manewrowo - przetokowych rozwijanych w kraju. Wyniki prowadzonych prac moga przynieść znaczne oszczędności w procesach projektowo - wdrożeniowych lokomotyw modulowych oraz w obniżeniu kosztów eksploatacyjnych (przeglady, naprawy, części zamienne, zapasy magazynowe, serwis).
\end{abstract}

\section{Wstęp}

Projektowanie, badania i wdrożenie do eksploatacji nowych oraz modernizowanych liniowych i manewrowych lokomotyw elektrycznych i spalinowych to przedsięwzięcie złożone, długotrwałe i kosztowne.

Cykl (proces) ten składa się przede wszystkim z wykonaniem następujących prac:

- opracowanie jednej lub kilku koncepcji lokomotywy najczęściej w oparciu o wymagania Użytkownika

- opracowanie założeń konstrukcyjnych wybranego wariantu lokomotywy wraz ze wstępnym usytuowaniem głównych zespołów i urządzeń

- przygotowanie wymagań i wytycznych na główne urządzenia, zespoły i układy (często wymagania wykonuje się dla kilku wariantów różnych producentów i dostawców urządzeń, zespołów i układów) proponowanych do zastosowania w projektowanej lokomotywie

- opracowanie dokumentacji konstrukcyjnej nowych układów, zespołów proponowanych do zastosowania w projektowanej lokomotywie

- wykonanie nowych układów, urządzeń i zespołów oraz przeprowadzenie dla nich niezbędnych testów, prób i badań
- opracowanie dokumentacji konstrukcyjnej lokomotywy (dla poszczególnych grup rysunkowych mechanicznych i elektrycznych) dla wybranego wariantu wraz z przeprowadzeniem niezbędnych obliczeń wytrzymałościowych, dynamicznych, cieplnych i trakcyjnych

- wykonanie prototypu (lub pierwszego egzemplarza) nowej lub modernizowanej lokomotywy

- opracowanie dokumentacji technicznej, w tym: Warunków Technicznych Wykonania, Warunków Technicznych Odbioru, Dokumentacji Techniczno-Ruchowej obejmującej Opis techniczny, Instrukcję obsługi (Podręcznik maszynisty), Dokumentów wydzielonych zespołów i głównych urządzeń, Katalogu części zamiennych, Dokumentacji Systemu Utrzymania, Programu Prób i Badań oraz Programu Prób Eksploatacyjnych

- przeprowadzenie prób i badań stacjonarnych i ruchowych lokomotywy wg Programu Prób i Badań

- przygotowanie dokumentów (w tym opinii) dla uzyskania terminowego świadectwa (lub zezwolenia) dopuszczenia do eksploatacji typu pojazdu kolejowego 
- przeprowadzenie prób eksploatacyjnych dla pierwszej nowej lokomotywy (dla lokomotyw modernizowanych próby eksploatacyjne moga być prowadzone dla kilku lub kilkunastu egzemplarzy)

- przygotowanie dokumentów (opinii) dla uzyskania bezterminowego świadectwa (lub zezwolenia) dopuszczenia do eksploatacji typu pojazdu kolejowego

- wdrożenie do produkcji nowych lub zmodernizowanych lokomotyw po wprowadzonych zmianach i uzupełnieniach $\mathrm{w}$ dokumentacji wynikających $\mathrm{z}$ realizacji wniosków z prób i badań (w tym również prób eksploatacyjnych) oraz nowych życzeń Użytkownika.

Przedstawiony powyżej proces jest kosztowny i należałoby dążyć do jego ograniczenia w projektowaniu, badaniach i wdrożeniu do eksploatacji nowych i zmodernizowanych lokomotyw. O ile w przypadku nowych lokomotyw jest zrozumiałe, że liczący się producent zagraniczny i krajowy będzie dążył do wprowadzenia na rynek usług kolejowych swoich nowoczesnych wyrobów, o tyle realizując procesy modernizacyjne zwłaszcza lokomotyw eksploatowanych w kraju można zdecydowanie obniżyć koszty procesu projektowania, badań i ich wdrażania do eksploatacji. Dotyczy to w zasadzie wykonania jednej dokumentacji konstrukcyjnej i technicznej oraz przeprowadzenie prób i badań dla jednego egzemplarza zmodernizowanej lokomotywy. Do tego jednak wymagane jest porozumienie głównych producentów (zajmujących się również procesami modernizacyjnymi) zwłaszcza taboru trakcyjnego (lokomotyw i zespołów trakcyjnych). Przykładem w przeszłości był proces modernizacji lokomotywy spalinowej serii SP32 przeznaczonej do ruchu pasażerskiego.

$\mathrm{Na}$ podstawie jednej dokumentacji konstrukcyjnej opracowanej na przełomie 1999 i 2000 roku przez Instytut Pojazdów Szynowych „Tabor” w Poznaniu i wykonanego oraz przebadanego prototypu zmodernizowanej lokomotywy przez Zakłady Naprawcze Lokomotyw Spalinowych w Pile produkcję zmodernizowanych lokomotyw uruchomiono również w Poznańskich Zakładach Naprawczych Taboru Kolejowego w Poznaniu oraz w Zakładach Naprawczych Taboru Kolejowego w Nowym Sączu.

Dla realizacji całego przedsięwzięcia wszystkie trzy firmy utworzyły (przed ogłoszonym przez Przedsiębiorstwo Państwowe PKP przetargiem) Konsorcjum „LOKSMOD”. Ogółem (mimo początkowo planowanej modernizacji 100 lokomotyw) zmodernizowano tylko 10 lokomotyw z czego $4 \mathrm{w}$ ZNLS Piła i po $3 \mathrm{w}$ PZNTK Poznań i ZNTK Nowy Sącz $[5,6]$.

Należy również wspomnieć, że na Międzynarodowych Targach w Poznaniu w 2001 r. zmodernizowana spalinowa lokomotywa do ruchu pasażerskiego serii SP32 uzyskała złoty medal.
Obniżkę kosztów jednostkowych związanych z wykorzystaniem tej samej dokumentacji konstrukcyjnej i technicznej, wyników prób i badań oraz kosztów związanych z dopuszczeniem uzyskuje się również wprowadzając do eksploatacji większą ilość nowych i zmodernizowanych lokomotyw tego samego typu (lub serii).

W wielu krajach dla obniżenia kosztów budowy zmodernizowanych lokomotyw wykorzystywane sa uniwersalne moduły, które zabudowane są w kilku typach (seriach) lokomotyw liniowych i manewrowych. W dalszej części artykułu zaprezentowano procesy wdrożenia platformy lokomotyw i ich konstrukcji modułowych dla lokomotyw eksploatowanych za granicą oraz w naszym kraju.

\section{Budowa modułowa lokomotyw liniowych i ma- newrowych budowanych i eksploatowanych za granicą}

Krajami przodującymi w budowie platformy lokomotyw liniowych i manewrowych są przede wszystkim Niemcy, natomiast nasi południowi sąsiedzi wyspecjalizowali się $\mathrm{w}$ modernizacjach lokomotyw spalinowych jednokabinowych, w których wykorzystano jednakowe moduły dla różnych serii lokomotyw i o różnym przeznaczeniu.

\subsection{Platforma liniowych lokomotyw elektrycznych i spalinowych}

Najwięcej różnych serii lokomotyw liniowych rozwijanych jako ,platforma” wprowadziły do eksploatacji firmy takie, jak Bombardier Transportation, Siemens z Krauss Maffei i Alstom [2, 8].

W/w firmy prace konstrukcyjne, badawcze i wdrożeniowe platformy o budowie modułowej liniowych lokomotyw elektrycznych i spalinowych, przeznaczonych do rożnych prac (prowadzenie pociagów pasażerskich i towarowych) rozpoczęły już w połowie lat 80-tych dwudziestego wieku.

Firma Bombardier Transportation produkuje rodzinę lokomotyw Traxx w wersjach elektrycznych, spalinowych i hybrydowych przeznaczonych do prowadzenia pociągów pasażerskich i towarowych. I tak np. [2]:

- Traxx AC jest lokomotywą elektryczną prądu zmiennego na napięcie zasilania $15 \mathrm{kV} 16{ }^{2} / 3 \mathrm{~Hz}$ i $25 \mathrm{kV} 50 \mathrm{~Hz}$ o mocy $5600 \mathrm{~kW}$

- Traxx MS jest lokomotywą elektryczną wielosystemową na napięcie zasilania $15 \mathrm{kV}$ i $25 \mathrm{kV}$ AC oraz $1,5 \mathrm{kV}$ i $3 \mathrm{kV}$ DC o mocach $5600 \mathrm{~kW}$, (a dla $1,5 \mathrm{kV}$ DC o mocy $4000 \mathrm{~kW}$ )

- Traxx DC jest lokomotywą elektryczną wielosystemową na napięcie $1,5 \mathrm{kV}$ i $3 \mathrm{kV}$ o mocach $5600 \mathrm{kV}$. Wszystkie lokomotywy elektryczne mogą być eksploatowane w zależności od przeznaczenia $\mathrm{z}$ prędkościami 140, $160 \mathrm{i}$ $200 \mathrm{~km} / \mathrm{h}$ 
- Traxx DE jest lokomotywą spalinową o mocy $2200 \mathrm{~kW}$ na prędkość $140 \mathrm{i} 160 \mathrm{~km} / \mathrm{h}$.

Jednakowymi elementami, które charakteryzują ich modułowość są pudła, ostoja, kabiny sterownicze, wózki trakcyjne, silniki trakcyjne i układy napędowe, systemy hamowania, centralne moduły napędowe i zintegrowane szafy urządzeń pomocniczych. Również powtarzalność rozmieszczenia elementów wyposażenia bardzo istotnie wpływa na koszt ich produkcji. Identyczność zastosowanych urządzeń w lokomotywach elektrycznych i spalinowych najlepiej obrazuje rys. 1 .

a)
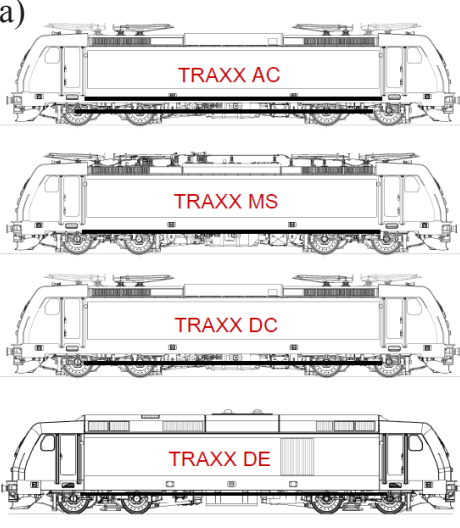

Wpólczynnik powtarzalności

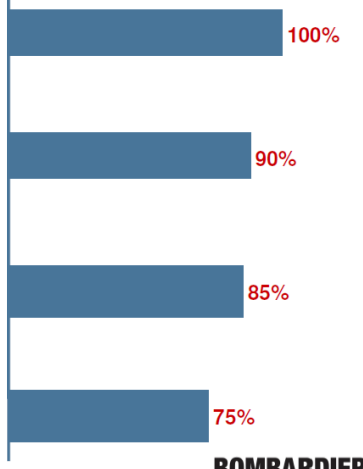

BOMBARDIER

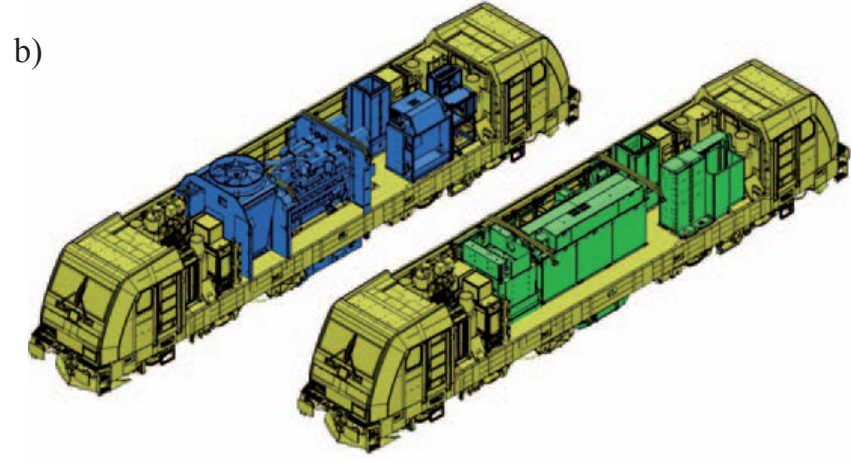

Rys.1. Powtarzalność (a) i identyczność części (b)

w różnych typach lokomotyw Traxx firmy Bombardier Transportation

Widoki ogólne przykładowych lokomotyw firmy Siemens przedstawiono na rys. $2 \div 4$.

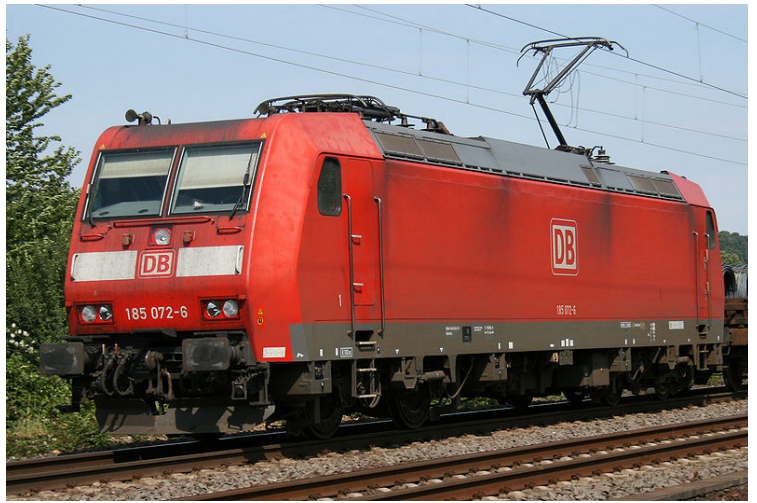

Rys.2. Lokomotywa elektryczna Traxx F 140 AC (seria 185)

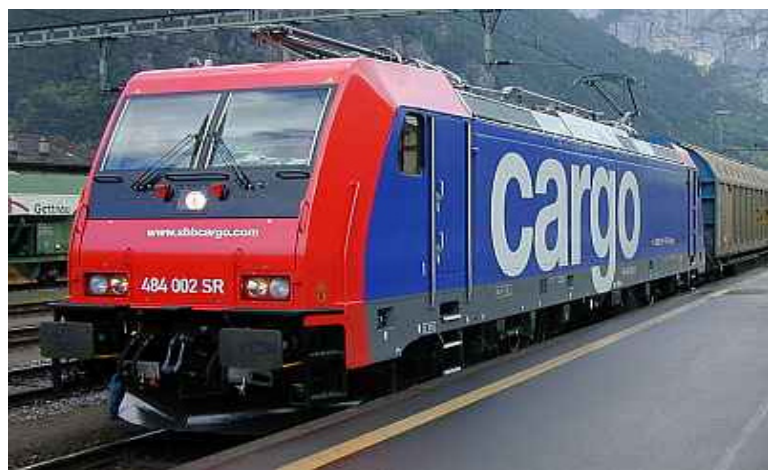

Rys.3. Lokomotywa elektryczna Traxx F 140 MS (seria 484)

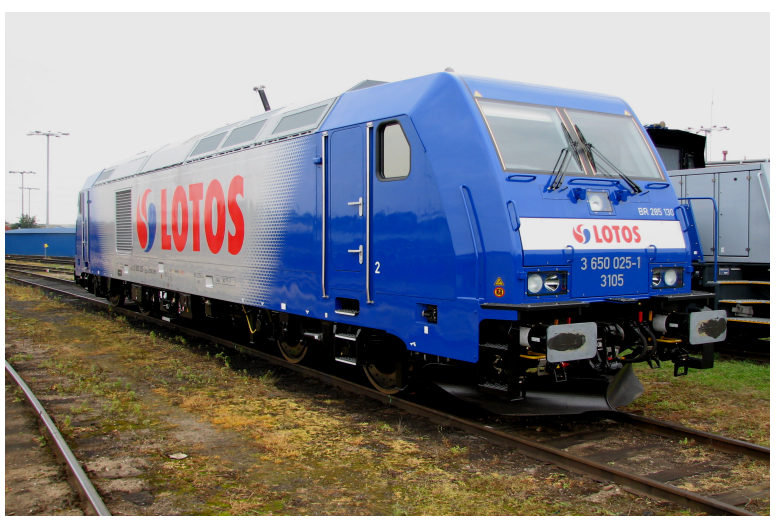

Rys.4. Lokomotywa spalinowa Traxx 140 DE (seria 285)

Firma Alstom proponuje modułowe konstrukcje lokomotyw elektrycznych typu Prima II.. W swojej ofercie przedstawia lokomotywy pasażerskie i uniwersalne (Prima II-P) o układzie osi Bo - Bo na prąd zmienny $25 \mathrm{kV} 50 \mathrm{~Hz}$ i $15 \mathrm{kV} 162 / 3 \mathrm{~Hz}$ oraz na prąd stały na napięcie $3 \mathrm{kV}$ o mocy $6000 \mathrm{~kW}$ i prędkości $200 \mathrm{~km} / \mathrm{h}$ oraz lokomotywy na prąd stały $1,5 \mathrm{kV}$ o mocy $4200 \mathrm{~kW}$ i prędkości $200 \mathrm{~km} / \mathrm{h}$.

Do ruchu towarowego o identycznym zasilaniu firma Alstom produkuje również lokomotywy Prima II-F o mocach 6400/6000/4200kW na prędkości $140 \mathrm{~km} / \mathrm{h}$. Wspólne rozwiązania stosowane $\mathrm{w}$ tych lokomotywach to przede wszystkim ostoje, pudła, kabiny sterownicze, wózki trakcyjne (dwa typy) oraz jednakowe rozmieszczenie głównych zespołów w nadwoziu. Ogólny widok lokomotywy wielosystemowej Prima II prezentuje rys.5.

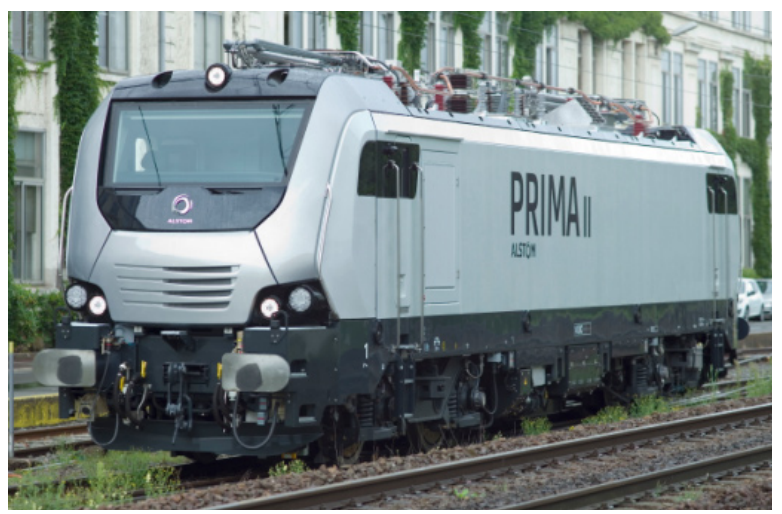

Rys.5. Widok lokomotywy wielosystemowej o budowie modułowej Prima II firmy Alstom 
W firmie Siemens produkowane są dwie rodziny lokomotyw - Siemens Eurosprinter i Siemens Vectron $[2,3,8]$.

Lokomotywy Siemens Eurosprinter budowane są na bazie lokomotywy E S 64 uzupełnionymi o szczegółowe pakiety dla każdego kraju i każdego klienta. Dobór odpowiednich pakietów umożliwia konfigurację właściwej lokomotywy.

Ze znanych lokomotyw Siemens Eurosprinter wymienić należy E S 64 P (lokomotywa pasażerska jednosysytemowa prądu zmiennego), E S 64 U 2 (lokomotywa uniwersalna dwusystemowa prądu zmiennego), E S 64 U 4 (lokomotywa uniwersalna czterosystemowa prądu stałego i zmiennego) i E S 64 F 4 (lokomotywa towarowa czterosystemowa prądu stałego $\mathrm{i}$ zmiennego).

Wspólne rozwiązania konstrukcyjne, wykorzystywane w większości lokomotyw to ostoje, kabiny sterownicze, ściany boczne przedziału maszynowego, dachy, systemy napędu, wózki trakcyjne, układy sterowania i diagnostyki, układy hamulcowe i urządzenia zasilania układów pomocniczych.

Charakterystyczne dla lokomotyw typu Eurosprinter jest to, że można na nich zabudować wszystkie krajowe pakiety bezpieczeństwa, jak również istnieje prosta zmiana zabudowy przedziału maszynowego.

Przykładowe widoki modułowych lokomotyw elektrycznych Siemens Eurosprinter przedstawiono na rys. 6 i 7.

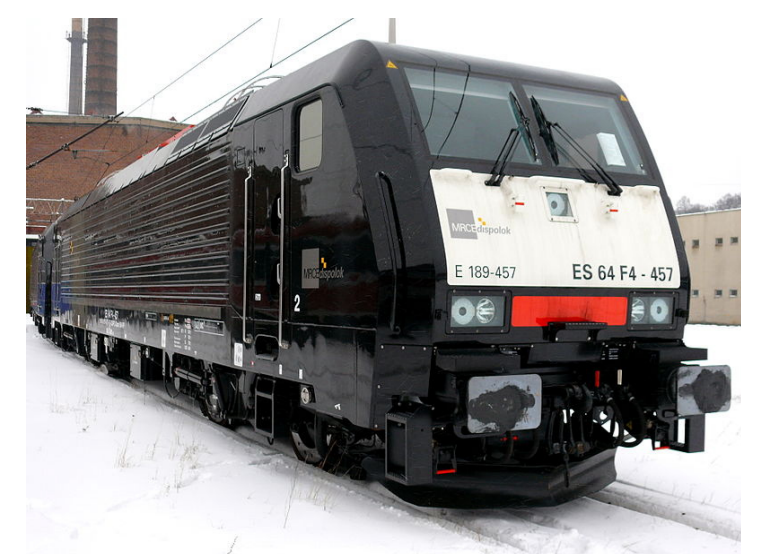

Rys.6. Lokomotywa elektryczna firmy Siemens do ruchu towarowego typu E S 64 F 4 (serii 189)

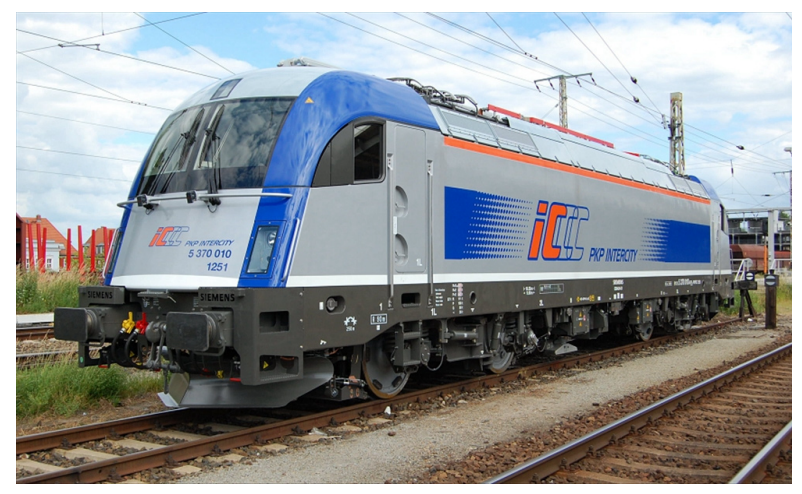

Rys.7. Lokomotywa elektryczna firmy Siemens uniwersalna typu E S 64 U 4 eksploatowana przez PKP Intercity
Drugą rodziną lokomotyw produkowanych przez Siemensa są lokomotywy Vectron przeznaczone do prowadzenia pociagów pasażerskich i są produkowane w wersji elektrycznej i spalinowej [12]. W swojej budowie zbliżone są do konstrukcji Eurosprintów.

Lokomotywy elektryczne Siemens Vectron są budowane na wszystkie napięcia zasilania wykorzystywane w Europie w zakresie mocy 5200 i $6400 \mathrm{~kW}$ i na prędkość 160 i $200 \mathrm{~km} / \mathrm{h}$.

Wspólne rozwiązania konstrukcyjne tego typu lokomotyw są podobne do lokomotyw z rodziny Eurosprinter. Lokomotywa spalinowa Vectron posiada zainstalowany silnik o mocy $2400 \mathrm{~kW}$ i może być eksploatowana z prędkościami do $160 \mathrm{~km} / \mathrm{h}$.

Widok ogólny lokomotywy elektrycznej firmy Siemens Vectron przedstawiono na rys. 8.

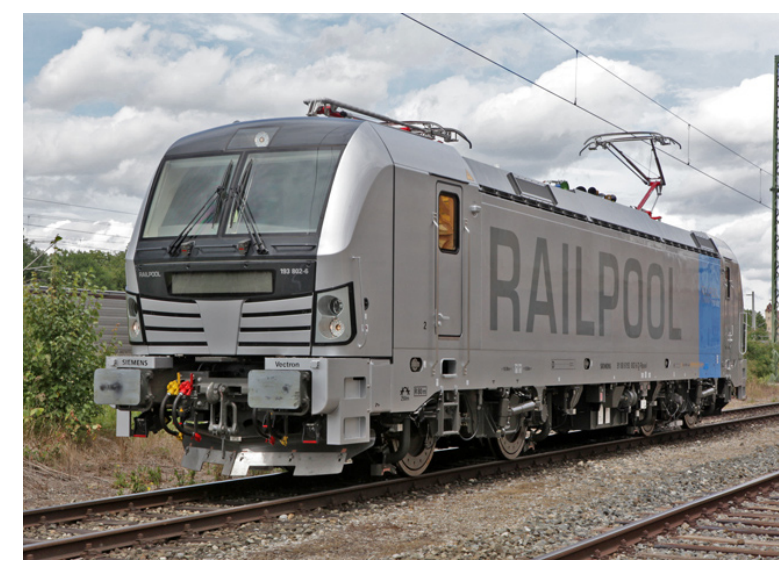

Rys.8. Lokomotywa dwusystemowa firmy Siemens Vectron

\subsection{Jednokabinowe lokomotywy spalinowe o bu- dowie modułowej}

Największe doświadczenie $\mathrm{w}$ projektowaniu, budowie oraz wdrażaniu do produkcji i eksploatacji jednokabinowych spalinowych lokomotyw modułowych (nowych i modernizowanych) przeznaczonych zasadniczo do prac manewrowych i przetokowych posiadają niemiecka firma Vossloh i czeska CzLoko $[10,13]$.

Firma Vossloh wprowadziła do eksploatacji kilka typów lokomotyw z przekładnią hydrauliczną i elektryczną (trzy i czteroosiowych) o różnym przeznaczeniu i mocy (rys.9).

a)
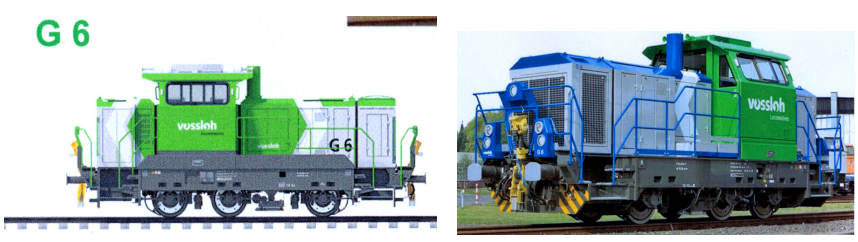


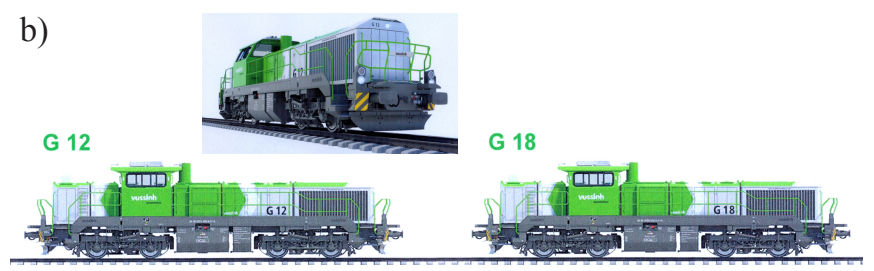

c)

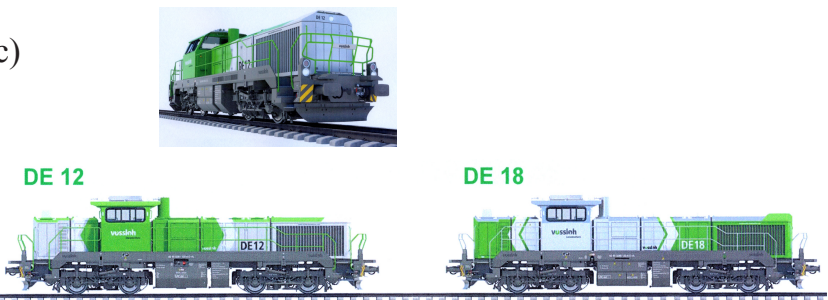

Rys.9. Modułowe lokomotywy spalinowe firmy Vossloh.

a) - trzyosiowa typu 66 o mocy $671 \mathrm{~kW}$ z przektadnia hydrauliczna

b) - czteroosiowe typu G12/G18 o mocach $1200 / 1800 \mathrm{~kW} \mathrm{z}$ przektadniami hydraulicznymi

c) - czteroosiowe typu DE 12/DE18 o mocach $1200 / 1800 \mathrm{kWz}$ przektadniami elektrycznymi

Modułowe konstrukcje lokomotyw przedstawionych na rys.9 charakteryzuje się tym, że:

- w budowie wszystkich typów lokomotyw użyto tych samych podzespołów niezależnie od typu przekładni i mocy silnika spalinowego

- w lokomotywach czteroosiowych (z przekładnią hydrauliczną i elektryczna) wykorzystano tę sama konstrukcje ostoi, kabiny, układy sterowania i układy hamulcowe oraz większość wyposażenia

- w lokomotywach trzyosiowych i czteroosiowych wykorzystane zostały te same konstrukcje kabin, układy sterowania oraz wiele części i podzespołów.

$\mathrm{Na}$ rys.10 zaprezentowano procentowy udział tych samych modułów, układów, urządzeń i zespołów w poszczególnych typach lokomotyw. Oznacza to, przyjmując za bazową lokomotywę czteroosiową z przekładnią elektryczną, że około $60 \%$ jej konstrukcji będzie wykorzystana $\mathrm{w}$ lokomotywie czteroosiowej $\mathrm{z}$ przekładnią hydrauliczna, a dalej z lokomotywy czteroosiowej można ocenić wykorzystanie tych samych urządzeń, części i układów na około 30\% w lokomotywie trzyosiowej o tym samym typie przekładni.

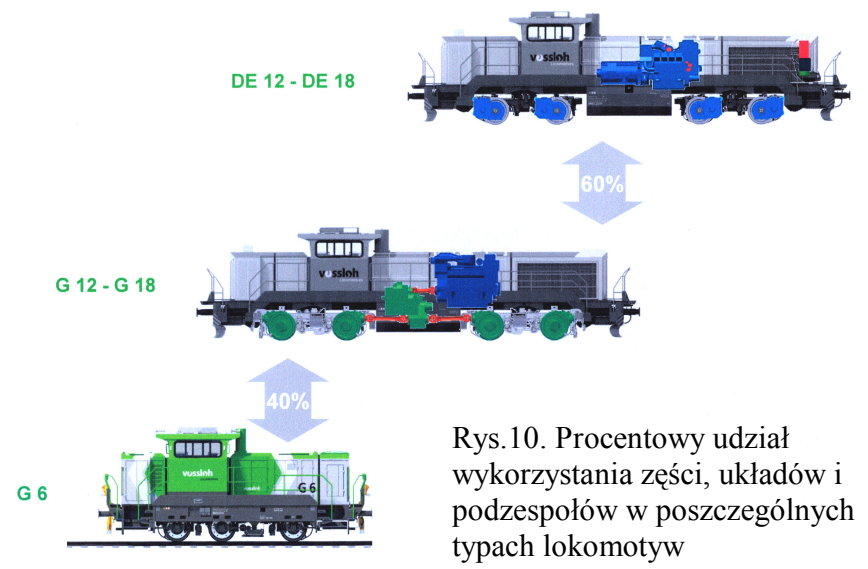

Korzyści jakie stwarza budowa modułowa (wg oceny dokonanej przez specjalistów firmy Vossloh) są następujące [10]:

- możliwość zastosowania jednakowych i tańszych części i podzespołów

- szybszy proces dopuszczenia w wyniku wykorzystania jednorazowo większości wyników badań

- krótsze terminy dostaw poszczególnych typów lokomotyw

- łatwość w dostępie do materiałów eksploatacyjnych i części zamiennych

- mniejsze zapasy magazynowe

- łatwość w utrzymaniu tych samych typów lokomotyw

- mniejsze koszty serwisowania (obniżenie czasu)

- niższe koszty szkoleń personelu obsługującego.

Firma CzLoko zajmuje się przede wszystkim modernizacja jednokabinowych lokomotyw spalinowych, w których został zastosowany system modułowy dający wiele wariantów rozwiązań, które można wykorzystać (lub dostosować) w całości lub oddzielnie w większości modernizowanych lokomotyw $[1,9]$.

W pierwszej zmodernizowanej lokomotywie typu 744 rozwiązania modułowe obejmowały moduł przedni, kabinę, moduł układów chłodzących i moduł zespołu prądotwórczego. Ponadto w obrębie każdego z modułów zastosowano system blokowy umożliwiający szybki sposób montażu i demontażu. Rozwiązanie to zdecydowanie uprościło, ułatwiło i obniżyło koszty modernizacji, utrzymania ( $w$ tym przeglądów i napraw). Ponadto poszczególne moduły lokomotyw zostały tak zaprojektowane by umożliwić łatwy dostęp do zabudowanych w nich urządzeń oraz umożliwić prosty i szybki ich montaż i demontaż.

Modernizacja lokomotyw nie obejmuje w zasadzie ostoi i układów biegowych, które poddaje się naprawie głównej oraz niewielkiej rekonstrukcji polegającej na poszerzeniu pomostów i przebudowie czołownic, które zostały wyposażone w elementy zabezpieczające przed skutkami ewentualnych zderzeń.

Modułowa kabina sterowania zapewniająca doskonała widoczność i komfort pracy obsługi może być stosowana w większości modernizowanych lokomotyw.

Ponadto w każdej modernizowanej lokomotywie są trzy inne moduly [1]:

- moduł pneumatyczny czołowy, w którym zabudowane jest wyposażenie obejmujące zbiorniki powietrza, sprężarkę, osuszacz i aparaturę pneumatyczną

- moduł elektryczny z hamulcem elektrodynamicznym, wentylatorami, aparatami i przyrządami elektrycznymi

- moduł zespołu prądotwórczego, w którym jest zabudowany silnik spalinowy, zespół prądnic, sekcje chłodzące, wentylatory oraz ich napędy.

System sterowania lokomotywą i napędem jest również systemem modułowym. 
Modułowy system proponowany przez CzLoko najlepiej przedstawia rys. 11 .

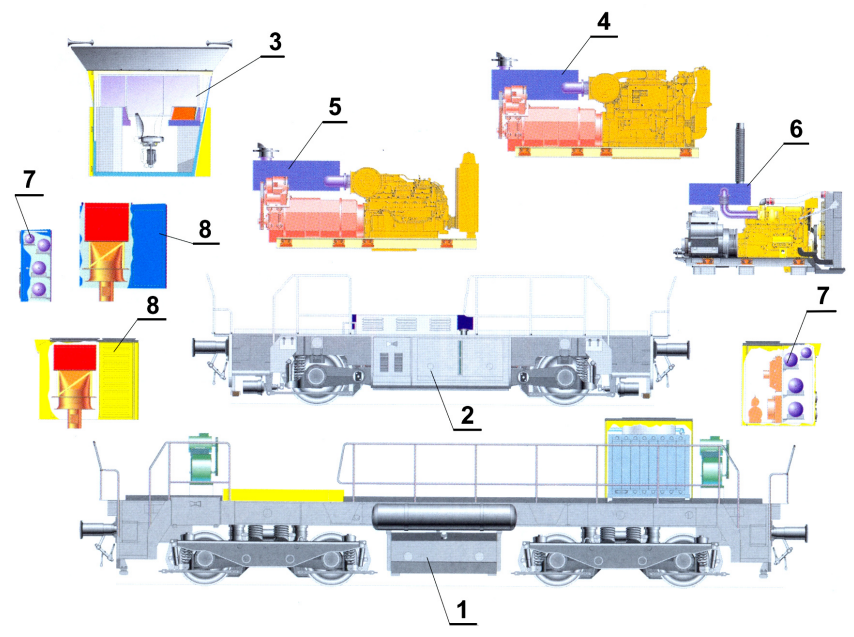

Rys.11. Podstawowe moduły zastosowane w modernizowanych przez CzLoko spalinowych lokomotywach dwu- i czteroosiowych.

1 - ostoja z wózkiem i zbiornikiem głównym oraz wentylatorami silników trakcyjnych i układem chłodzenia lokomotywy czteroosiowej

2 - ostoja z wózkami napędnymi lokomotywy dwuosiowej

3 - modul kabiny

4 - zespót prqdotwórczy z silnikiem CAT 3508

5 - zespót pradotwórczy z silnikiem CAT C27

6 - zespót prqdotwórczy z silnikiem CAT C15

7 - modut pneumatyczny

8 - modut elektryczny z hamulcem elektrodynamicznym

Prezentowany przykładowy modułowy system wykorzystywany w modernizacji lokomotyw jednokabinowych świadczy o dużej uniwersalności zastosowania modułów kabiny sterowniczej, urządzeń elektrycznych i pneumatycznych i zespołu prądotwórczego, a ponadto istnieje możliwość zastosowania również trzech różnych modułów zespołów prądotwórczych opartych na silnikach CAT C15, CAT C27, CAT 3508 C/CAT 3512 C o różnych mocach [9].

Zastosowane systemy wykorzystujące poszczególne moduły najlepiej obrazują również widoki zmodernizowanych lokomotyw przedstawionych na rys. $12 \div 14$.

a)

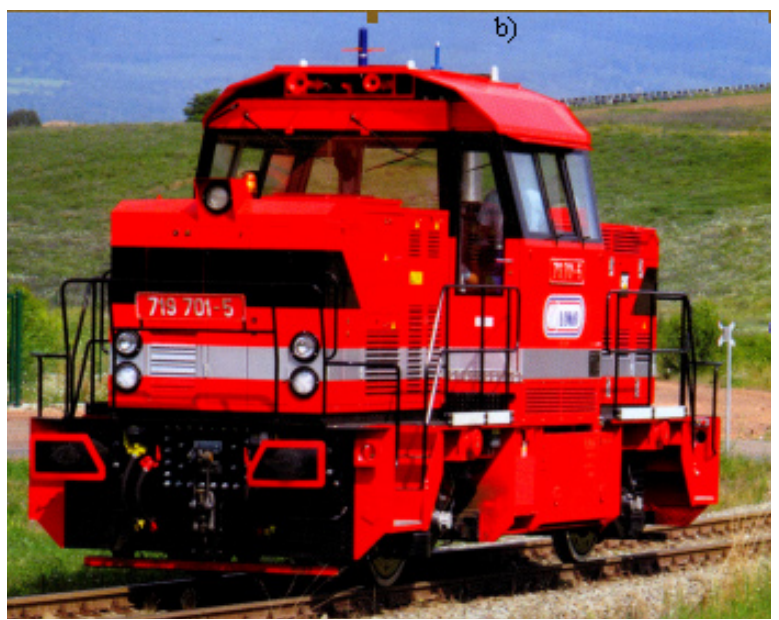

b)

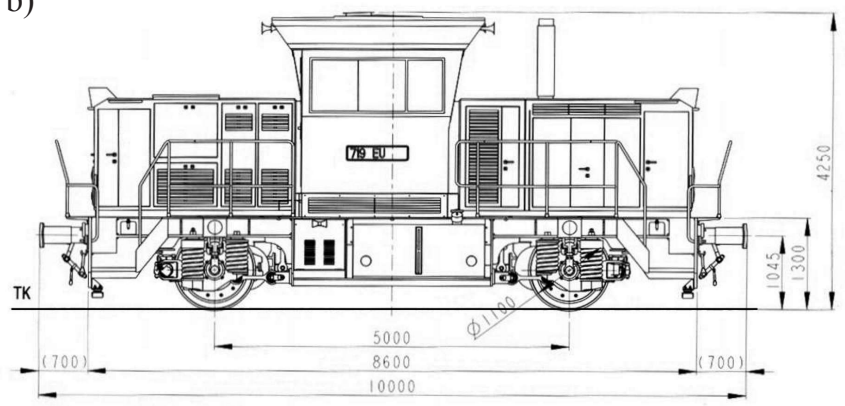

Rys.12. Modułowa konstrukcja lokomotywy dwuosiowej typu 719 o mocy $403 \mathrm{~kW}$ a) - widok ogólny b) - główne wymiary

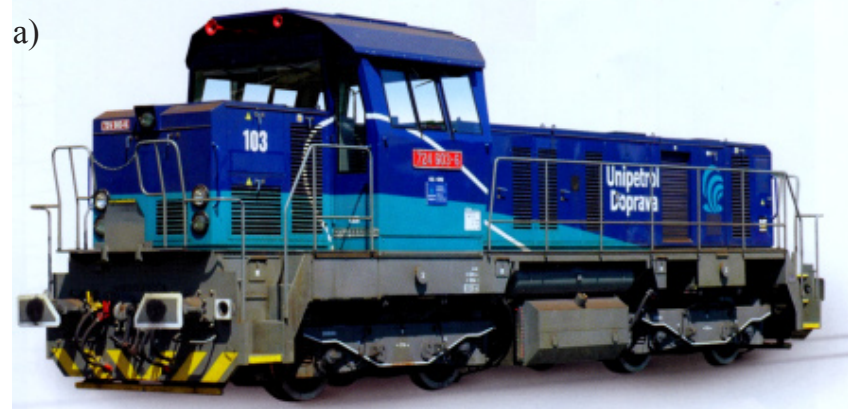

b)

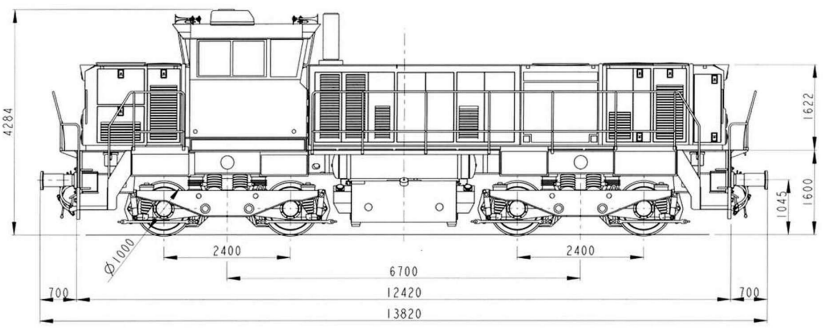

Rys.13. Modułowa konstrukcja lokomotywy czteroosiowej typu 724.6/724.77 o mocach 403 lub 709kW a) - widok ogólny b) główne wymiary
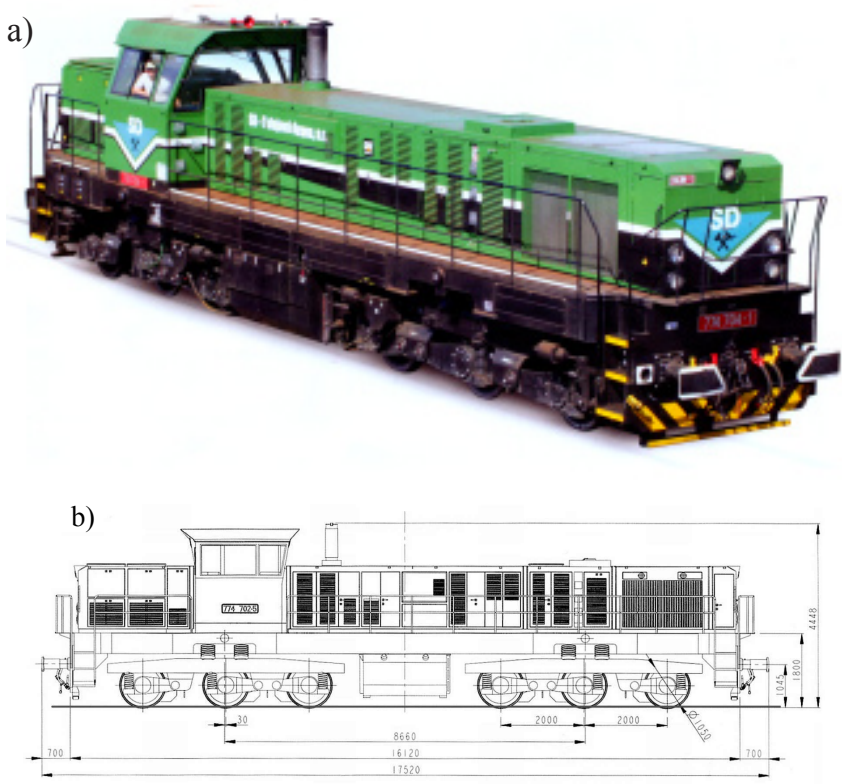

Rys.14. Modułowa konstrukcja lokomotywy sześcioosiowej typu 774.7 o mocach 1000 lub $1550 \mathrm{~kW}$ a) - widok ogólny b) - główne wymiary 


\section{Budowa modulowa lokomotyw liniowych $w$ Polsce}

W Polsce prace nad platformą lokomotyw liniowych oraz konstrukcjami modułowymi modernizowanych spalinowych lokomotyw jednokabinowych rozpoczęto dopiero w ostatnich kilku latach wykorzystując doświadczenia innych krajów europejskich.

\subsection{Platforma liniowych lokomotyw elektrycznych i spalinowych}

Prace konstrukcyjne badawcze i wdrożeniowe nad stworzeniem platformy lokomotyw liniowych przeznaczonych do eksploatacji z pociagami pasażerskimi i towarowymi rozpoczęły dwa prężne zakłady Pojazdy Szynowe PESA Bydgoszcz S.A. Holding oraz Zakłady Naprawcze Lokomotyw Elektrycznych w Gliwicach (obecnie Newag Gliwice S.A.) [3,4].

PESA Bydgoszcz wykorzystując obecny potencjał intelektualny i technologiczny firmy w latach 20112012 wykonała własną lokomotywę Gama-Marathon - pierwszą z całej platformy tego rodzaju pojazdów pod nazwą Gama.

W skład całej platformy lokomotyw o układach osi $\mathrm{B}_{\mathrm{o}}$ - $\mathrm{B}_{0}$, którą przedstawiono na rys. 15 wchodzą:

- lokomotywy wielosystemowe o mocy $5600 \mathrm{~kW}$ na napięcia $15 \mathrm{kV} 16^{2} /{ }_{3} \mathrm{~Hz}, 25 \mathrm{kV} 50 \mathrm{~Hz} \mathrm{AC} 3 \mathrm{kV}$ DC i na prędkości $160 \mathrm{i} 190 \mathrm{~km} / \mathrm{h}$

- lokomotywy jednosystemowe o mocy $5600 \mathrm{~kW}$, na prąd stały $3 \mathrm{kV}$ i prędkości 160 i $190 \mathrm{~km} / \mathrm{h}$

- lokomotywa spalinowa o mocy $2200 \mathrm{~kW}$ na prędkość $160 \mathrm{~km} / \mathrm{h}$.

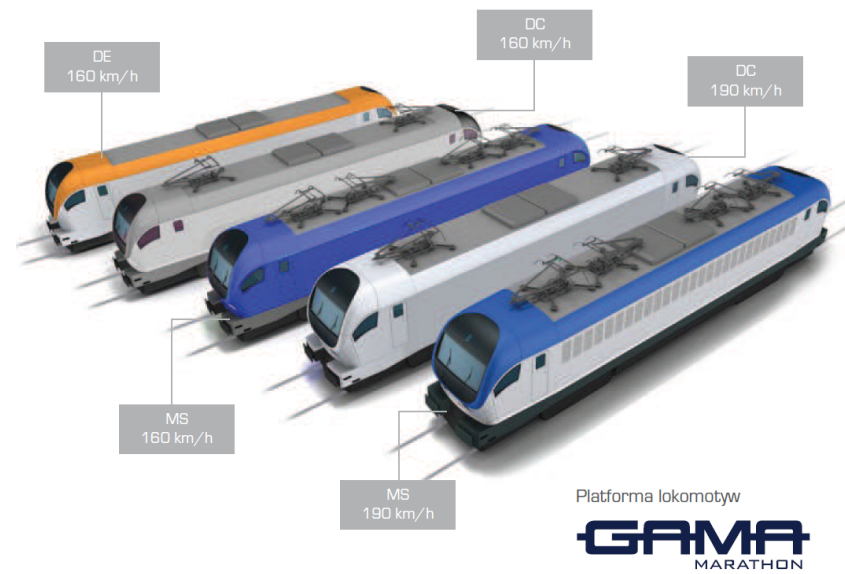

Rys.15. Platforma lokomotyw Gama Marathon firmy PESA Bydgoszcz

Wspólne główne układy i zespoły w tych lokomotywach to: pudła, kabiny sterownicze, wózki trakcyjne z usprężynowaniem i napędami, układy pociagowozderzne, wyposażenie w zakresie układów pneumatycznych, hamulcowych, chłodzących, diagnostyki i sterowania.

Pierwsza zrealizowana i przebadana lokomotywa o oznaczeniu 111Ed, której widok przedstawiono na rys.16, jest lokomotywą jednosystemową prądu stałego $3 \mathrm{kV}$, o mocy $5600 \mathrm{~kW}$ na prędkość $140 \div 190 \mathrm{~km} / \mathrm{h}$ [11].
W lokomotywie tej, po raz pierwszy w konstrukcjach krajowych, zastosowano moduł WC dla obsługi oraz zabudowano dodatkowy zespół prądotwórczy (silnik spalinowy + prądnica synchroniczna) umożliwiający realizację prac manewrowych lub dojazdów do składu wagonów na torach bez sieci trakcyjnej.

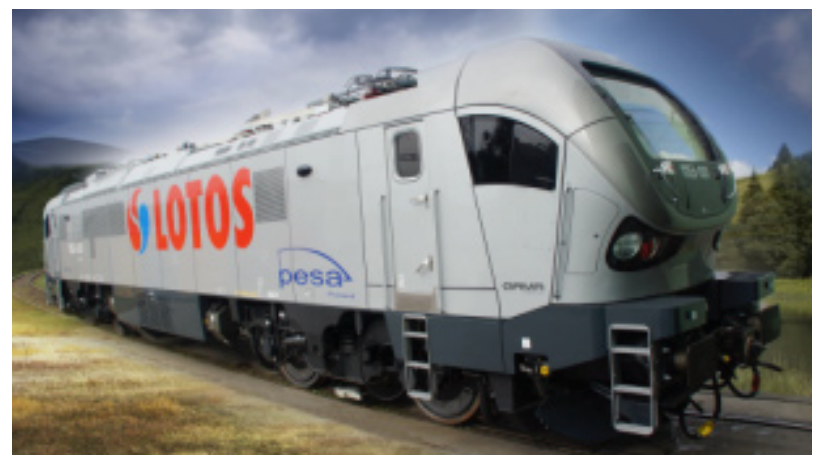

Rys.16. Lokomotywa elektryczna typu 111 Ed firmy PESA Bydgoszcz

Zakłady Naprawcze Lokomotyw Elektrycznych w Gliwicach (obecnie Newag - Gliwice) opracowały również platformę nowoczesnych lokomotyw liniowych elektrycznych i spalinowych w oparciu o konstrukcję modułową, tzn. wykorzystująca maksymalną ilość wspólnych elementów. W skład całej platformy lokomotyw czteroosiowych o nazwie Griffin wchodzą [14]:

lokomotywy jednosystemowe (prąd stały $3 \mathrm{kV}$ ) o mocy $5600 \mathrm{~kW}$, na prędkość $140 \mathrm{~km} / \mathrm{h}$ (typ E4 DCU) i $200 \mathrm{~km} / \mathrm{h}$ (typ E4 DCP)

lokomotywy wielosystemowe (prąd zmienny $15 \mathrm{kV}$ $16{ }^{2} /{ }_{3} \mathrm{~Hz}$ i $25 \mathrm{kV} 50 \mathrm{~Hz}$ ) o mocy $5600 \mathrm{~kW}$ na prędkość $160 \mathrm{~km} / \mathrm{h}$ (typ E4 ACU) i $200 \mathrm{~km} / \mathrm{h}$ (typ E4 ACP)

lokomotywy wielosystemowe (prąd stały $3 \mathrm{kV}$ i prąd zmienny $15 \mathrm{kV} \quad 16{ }^{2} /{ }_{3} \mathrm{~Hz}$ i $\left.25 \mathrm{kV} \quad 50 \mathrm{~Hz}\right)$ o mocy $5600 \mathrm{~kW}$ na prędkość $160 \mathrm{~km} / \mathrm{h}$ (typ E4 MSU) i $200 \mathrm{~km} / \mathrm{h}$ (typ E4 MSP)

lokomotywa spalinowa typ D4 MSU o mocy $2300 \mathrm{~kW}$ na prędkość $160 \mathrm{~km} / \mathrm{h}$.

W lokomotywach typu Griffin wspólne elementy i zespoły to: pudła, ostoje, kabiny sterownicze, wózki trakcyjne, zespoły napędowe, systemy diagnostyczne i sterujące, systemy hamulcowe oraz układy pociagowo-zderzne.

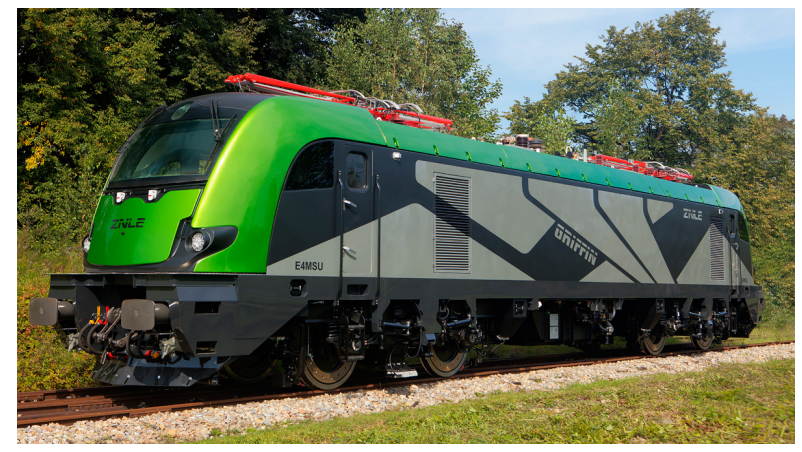

Rys.17. Lokomotywa elektryczna wielosystemowa typu E4 MSU Griffin firmy Newag - Gliwice 
Należy zaznaczyć, że lokomotywy 111 Ed (Gama Marathon) i E4 MSU Griffin były bardzo dobrze ocenione przez fachowców podczas prezentacji na INNOTRANS 2012. Obie firmy wprowadzające modułowe konstrukcje lokomotyw do produkcji w pełni zabezpieczą zapotrzebowanie głównych przewoźników krajowych na nowoczesne lokomotywy liniowe w wersjach elektrycznych i spalinowych [3].

\subsection{Modułowe konstrukcje jednokabinowych lo- komotyw spalinowych}

Pierwsza lokomotywa spalinowa o budowie modułowej została wykonana $\mathrm{w}$ wyniku modernizacji lokomotywy serii SM42 przez Pojazdy Szynowe PESA Bydgoszcz S.A. Holding i Cz Loko Česka Třebova (Republika Czeska) w 2009 roku. W lokomotywie tej zabudowano dwa moduły trakcyjne, a konstrukcja modułowa została oparta o doświadczenia zdobyte przez Cz Loko w prowadzonych krajowych (czeskich) modernizacjach lokomotyw spalinowych [3, 4].

Jedynymi zespołami, które nie uległy większym rekonstrukcjom były ostoja oraz wózki, które poddano jednak naprawie głównej i zmianom dostosowawczym.

Modułową konstrukcję lokomotywy przedstawiono na rys. 18 .

Każdy moduł trakcyjny składa się z samonośnej obudowy, ramy pośredniej pod zespół prądotwórczy, który tworzą silnik spalinowy CAT C 15 i prądnica 1F C2 401 z prostownikiem, agregat chłodzący silnik spalinowy, zbiornik kompensacyjny płynu chłodzącego, prądnicę pomocniczą, sprężarkę powietrza, zespoły układów hydrostatycznych, układ wlotu powietrza i układ wylotu spalin, podgrzewacz układu chłodzenia silnika spalinowego, wzbudnicę statyczną i reflektory czołowe.

W module pneumatycznym znajduje się większość wyposażenia pneumatycznego ( $\mathrm{w}$ tym zbiorniki powietrza i tablica) oraz wentylator chłodzenia silników trakcyjnych wózka przedniego, stacjonarny system gaśniczy oraz urządzenia do smarowania obrzeży kół. Moduł wyposażenia elektrycznego posiada zabudowane elementy wyposażenia elektrycznego, wentylator silników trakcyjnych tylnego wózka oraz stałe urządzenie gaśnicze.
Moduł kabiny posiada nowy, nowoczesny kształt i ergonomiczne pulpity.

Wzajemne połączenie modułów pomiędzy sobą oraz z ostoją zrealizowano poprzez system korytek, do których wchodzą profile gumowe w kształcie „L” i „U”.

Konstrukcja modułowa umożliwia ponadto szybką ich wymianę z uszkodzonymi bądź planowanymi do naprawy podzespołami.

Ponadto zrealizowana wersja lokomotywy dwuagregatowej pozwoli na ich mniejsze zużycie paliwa, ponieważ podczas pracy $\mathrm{z}$ wykorzystaniem tylko jednego silnika (najczęściej występujący tryb pracy manewrowej) następować będzie wyższe wykorzystanie mocy, a więc wyższy reżim temperaturowy niż w lokomotywach $\mathrm{z}$ jednym silnikiem o podwójnej mocy.

Ponieważ niższe będą ceny części zamiennych oraz niższe koszty ich magazynowania, także zmniejszą się koszty utrzymania, zużycia paliwa a uzyska się zwiększenie siły pociągowej lokomotywy i bardzo wysoki wskaźnik gotowości technicznej.

Widok ogólny lokomotywy przedstawiono na rys.19.

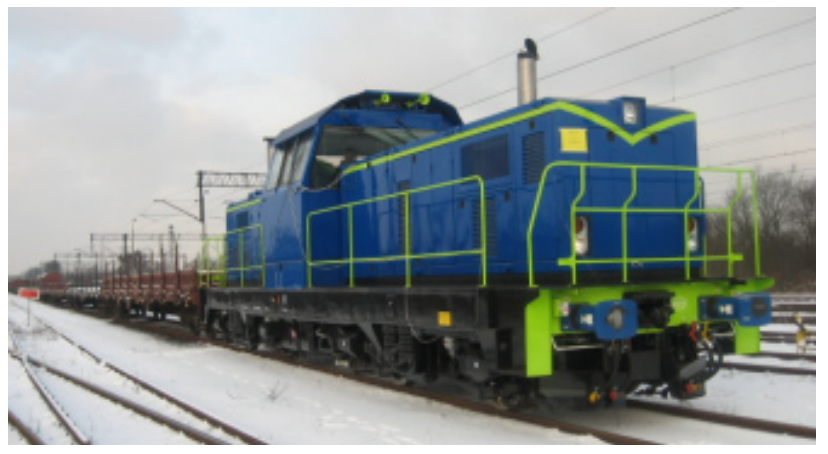

Rys.19. Widok ogólny modułowej lokomotywy typu 6Dk modernizowanej na bazie lokomotywy serii SM42

Druga lokomotywą o budowie modułowej jest zaprojektowana przez Instytut Pojazdów Szynowych „Tabor” w Poznaniu jednokabinowa lokomotywa spalinowa typu 6Di zbudowana na bazie zmodernizowanej lokomotywy serii SM42. Na ostoi, która zostaje zmodyfikowana tzn. na całej powierzchni przyspawana jest płyta o grubości $20 \mathrm{~mm}$ przystosowana do zabudowy układów wentylacyjnych silników trakcyjnych, kanałów kablowych i pneumatycznych oraz nowych modułów, takich jak [7]:

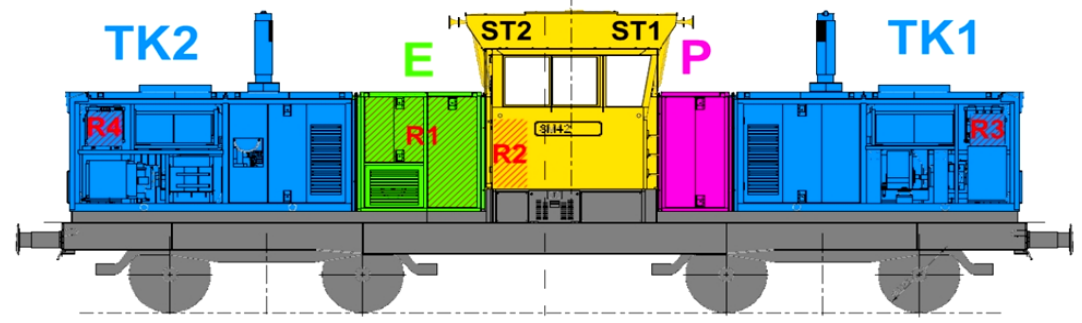

$\mathbf{K}$ - moduł kabiny sterowniczej;

TK1, TK2 - moduł trakcyjny;

E - moduł elektryczny;

$\mathbf{P}$ - moduł pneumatyczny;

$\mathbf{R} 1, \mathbf{R 2}, \mathbf{R 3}, \mathbf{R} 4$ - rozdzielnie;

ST1, ST2 - stanowiska sterownicze

Rys.18. Ogólne rozmieszczenie modułów w zmodernizowanej 
- moduł kabiny sterowniczej

- czołowy moduł pneumatyczny

- czołowy moduł sprężarkowo - wentylacyjny

- moduł zespołu prądotwórczego

- moduł układów i zespołów elektrycznych.

Moduły są połączone ze sobą oraz z kabiną i ostoją za pośrednictwem łączników ceownikowych z uszczelniaczami zapewniając ich szczelność i szybki demontaż z lokomotywy za pośrednictwem suwnicy z typowym zawiesiem. W lokomotywie zabudowane zostały te same silniki trakcyjne typu $1 \mathrm{LN}$ lub $1 \mathrm{LNa}$, które podlegać będą naprawie głównej i zabiegom dostosowawczym.

Ponadto pozostałe nowoczesne urządzenia: aparaty, maszyny i zespoły zastosowane w lokomotywie (w poszczególnych modułach) to:

- silniki spalinowe spełniające wymagania w zakresie emisji substancji szkodliwych do atmosfery - Stage IIIb - np.: D2842 LE firmy MAN o mocy $662 \mathrm{~kW}$ lub firmy CAT typu C27 o mocy $652 \mathrm{~kW}$

- zespół prą̨nic synchronicznych z zabudowaną wzbudnicą

- tablica pneumatyczna i sprężarka śrubowa $z$ napędem elektrycznym

- dwa niezależne pulpity i fotele (w module kabiny) oraz nowoczesne urządzenia i aparaty elektryczne. Moduł kabiny został odizolowany od ostoi za pomocą amortyzatorów gumowometalowych, a dach przystosowany do zabudowy schładzacza lub wentylatora wyciagowego

- mikroprocesorowe układy sterowania i diagnostyki, w tym układy przeciwpoślizgowe

- elektroniczne prędkościomierze, rejestratory głównych parametrów pracy, zespoły łączności radiowej i urządzenia bezpieczeństwa

- halogenowe oświetlenie zewnętrzne i lampy sygnałowe.

Widok ogólny rozmieszczenia modułów na lokomotywie przedstawiono na rys.20, a zestawienie głównych modułów na rys. 21 .

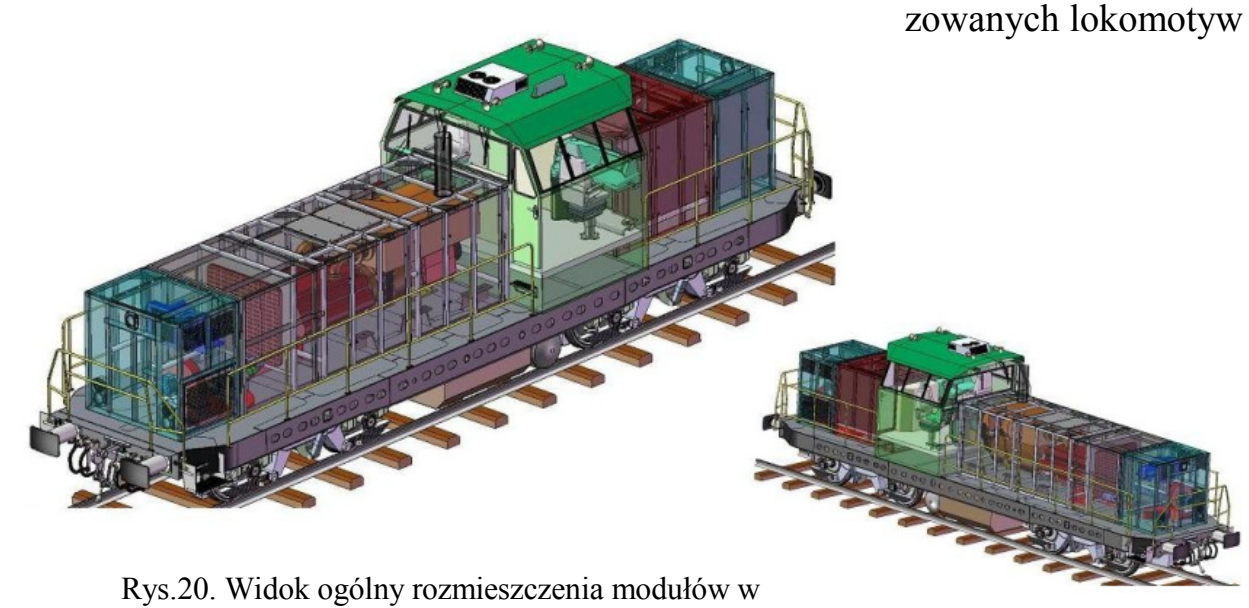

zmodernizowanej lokomotywie typu 6Di serii SM42

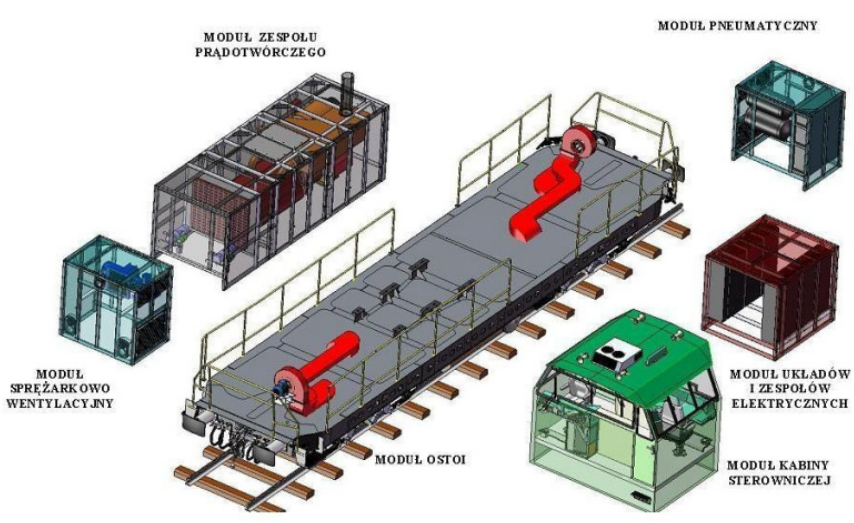

Rys. 21. Ogólne zestawienie głównych modułów w zmodernizowanej spalinowej lokomotywie jednokabinowej typu 6Di (SM42)

W Instytucie Pojazdów Szynowych „Tabor” w Poznaniu powstają wstępne projekty modułowych konstrukcji lokomotyw w oparciu o lokomotywy eksploatowane, takie jak: 401Da, 1D (SM30), 6D (SM42), 411D (SM31) i TEM2 (SM48), w których zamierza się również zabudować napędy hybrydowe w oparciu o wysokowydajne zasobniki energii [4].

Główne parametry tych lokomotyw wymienionych powyżej przedstawiono $\mathrm{w}$ tablicy 1 . Pozwoli to na zdecydowane obniżenie kosztów projektowania, wdrożenia do produkcji, wykonania prób i badań oraz procesów dopuszczenia do eksploatacji.

\section{Podsumowanie}

Przedstawione $\mathrm{w}$ artykule procesy projektowe $\mathrm{i}$ wdrożeniowe nowych lub modernizowanych lokomotyw można zdecydowanie uprościć, a jednocześnie obniżyć ich koszty. Świadczą o tym przedstawione przykłady wykorzystania platform lokomotyw oraz konstrukcji modułowych w innych krajach, między innymi w Niemczech i Czechach. Dotyczy to zarówno lokomotyw liniowych jak i manewrowych.

Największe korzyści uzyskuje się $\mathrm{w}$ uproszczeniu procesów projektowania lokomotyw, a tym samym ich kosztów. Ponadto zdecydowanie obniża się koszty prowadzonych prób i badań (w szczególności dla nowych układów, zespołów i urządzeń) oraz przyspiesza prace związane $\mathrm{z}$ dopuszczeniem nowych i zmodernizowanych lokomotyw do eksploatacji. 
Tablica 1

Podstawowe parametry wybranych lokomotyw spalinowych jednokabinowych eksploatowanych w Polsce

\begin{tabular}{|c|c|c|c|c|c|c|c|}
\hline \multirow[b]{2}{*}{ L.p. } & \multirow[b]{2}{*}{ Wielkość lub parametr } & \multirow{2}{*}{$\begin{array}{l}\text { Jedno- } \\
\text { stka }\end{array}$} & \multicolumn{5}{|c|}{ Typ lub seria lokomotywy } \\
\hline & & & $401 \mathrm{Da}$ & $\begin{array}{c}1 \mathrm{D} \\
(\mathrm{SM} 30) \\
\end{array}$ & $\begin{array}{c}6 \mathrm{D} \\
(\mathrm{SM} 42) \\
\end{array}$ & $\begin{array}{c}411 \mathrm{D} \\
\text { (SM31) } \\
\end{array}$ & $\begin{array}{c}\text { TEM2 } \\
\text { (SM48) } \\
\end{array}$ \\
\hline 1. & Układ osi & - & $\mathrm{C}$ & $\mathrm{B}_{\mathrm{o}}-\mathrm{B}_{\mathrm{o}}$ & $\mathrm{B}_{\mathrm{o}}-\mathrm{B}_{\mathrm{o}}$ & $\mathrm{C}_{\mathrm{o}}-\mathrm{C}_{\mathrm{o}}$ & $\mathrm{C}_{0}-\mathrm{C}_{\mathrm{o}}$ \\
\hline 2. & Szerokość toru & $\mathrm{mm}$ & 1435 & 1435 & 1435 & 1435 & $1435 / 1520$ \\
\hline 3. & Moc znamionowa & $\mathrm{kW}$ & 257 & $220(257)$ & 588 & 885 & 883 \\
\hline 4. & Prędkość maksymalna & $\mathrm{km} / \mathrm{h}$ & 60 & 60 & 90 & 80 & 100 \\
\hline 5. & Masa lokomotywy & $\mathrm{Mg}$ & 40,5 & 36 & 74 & 111,5 & 115,8 \\
\hline 6. & $\begin{array}{l}\text { Typ i moc silnika spali- } \\
\text { nowego }\end{array}$ & $\mathrm{kW}$ & $\begin{array}{c}12 \mathrm{~V} \\
1416 \mathrm{~A} \\
\text { (licencja } \\
\text { Henschel) }\end{array}$ & 3DVSRa-350 & a $8 C 22-5880$ & a8C $22 W$ & PDIM \\
\hline 7. & Typ prądnicy głównej & $\mathrm{kW}$ & LSPb-493 & $\begin{array}{c}\text { PABOM- } \\
186 / \mathrm{a}\end{array}$ & $\begin{array}{c}\text { LSPa } \\
740\end{array}$ & $\begin{array}{c}\text { LSPa } \\
930 \\
\end{array}$ & $\begin{array}{c}\text { GP } \\
300 \mathrm{BYZ} \\
\end{array}$ \\
\hline 8. & $\begin{array}{c}\text { Typ prądnicy pomocni- } \\
\text { czej }\end{array}$ & $\mathrm{kW}$ & LSPc-280 & Pw-114a & $\begin{array}{c}\text { LSPa } \\
220\end{array}$ & $\begin{array}{c}\text { LSPm } \\
280\end{array}$ & $\begin{array}{l}\text { MWG- } \\
\text { 25/9Y2 }\end{array}$ \\
\hline 9. & $\begin{array}{l}\text { Typ i moc silnika trak- } \\
\text { cyjnego }\end{array}$ & $\mathrm{kW}$ & LSa-430-173 & LKa-310-60 & LSa-430-173 & LSm-430 & ED-118-AY2 \\
\hline 10. & Rodzaj przekładni & - & $\mathrm{DC} / \mathrm{DC}$ & $\mathrm{DC} / \mathrm{DC}$ & $\mathrm{DC} / \mathrm{DC}$ & $\mathrm{DC} / \mathrm{DC}$ & $\mathrm{DC} / \mathrm{DC}$ \\
\hline 11. & $\begin{array}{l}\text { Przełożenie przekładni } \\
\text { osiowej }\end{array}$ & - & $\begin{array}{c}75 / 17= \\
4,41\end{array}$ & $\begin{array}{c}72 / 13= \\
5,54 \\
\end{array}$ & $\begin{array}{c}75 / 17= \\
4,41 \\
\end{array}$ & $\begin{array}{c}58 / 17= \\
3,41 \\
\end{array}$ & 4,41 \\
\hline 12 . & System hamulca & - & $\begin{array}{l}\text { pneumaty- } \\
\text { czny } \\
\text { Oerlikon }\end{array}$ & $\begin{array}{l}\text { pneumaty- } \\
\text { czny } \\
\text { Oerlikon } \\
\end{array}$ & $\begin{array}{l}\text { pneumaty- } \\
\text { czny } \\
\text { Oerlikon } \\
\end{array}$ & $\begin{array}{l}\text { pneumaty- } \\
\text { czny } \\
\text { Oerlikon } \\
\end{array}$ & $\begin{array}{l}\text { Oerlikon, } \\
\text { SAB-Wabco }\end{array}$ \\
\hline 13. & Producent & - & $\begin{array}{c}\text { Fablok } \\
\text { Chrzanów }\end{array}$ & $\begin{array}{c}\text { Fablok } \\
\text { Chrzanów }\end{array}$ & $\begin{array}{c}\text { Fablok } \\
\text { Chrzanów }\end{array}$ & $\begin{array}{c}\text { Fablok } \\
\text { Chrzanów }\end{array}$ & $\begin{array}{c}\text { ZBM } \\
\text { Briańsk }\end{array}$ \\
\hline 14. & $\begin{array}{l}\text { Ilość lokomotyw, w } \\
\text { których można zastoso- } \\
\text { wać budowę modułową }\end{array}$ & - & 450 & 500 & 1000 & 150 & 80 \\
\hline
\end{tabular}

Pozostałe zalety wprowadzenia platformy i konstrukcji modułowych to zastosowanie tych samych rozwiazań i nowych zespołów i urządzeń w innych typach (seriach) lokomotyw wdrażanych do produkcji i eksploatacji, zmniejszenie zapasów magazynowych dla materiałów eksploatacyjnych i części zamiennych, szybki serwis i łatwość utrzymania lokomotyw oraz niższe koszty szkolenia obsługi, w tym maszynistów i służb serwisowych.

Miejmy nadzieję, że również w Polsce - zarówno główni Użytkownicy (spółki PKP oraz prywatni operatorzy kolejowi) będa zainteresowani wdrożeniem do eksploatacji platformy lokomotyw i ich modułowych konstrukcji.

\section{Bibliografia}

[1.] Bittner J., KranekJ., Skala B., Sramek M.: Maty atlas lokomotiv 2013, Specjalni vydani pro CZ LOKO, a.s. Czeskă Třebova, 2013.

[2.] Chiżyński J.: Bombardiery $i$ Siemensy $w$ Polsce, Świat Kolei, $n$ r 2/2011.

[3.] Czerwiński J., Marciniak Z.: Modułowe konstrukcje jednokabinowych spalinowych lokomotyw manewrowych. Prace naukowe Politechniki Warszawskiej. Zeszyt 98. Transport. Środki i infrastruktura transportu, Warszawa, 2013.

[4.] Marciniak Z.: Projekty modernizacyjne spalinowych lokomotyw liniowych|i manewrowych wykonanych $w$ Instytucie Pojazdów Szynowych, Logistyka, nr 4/2012.
[5.] Marciniak Z.: Zmodernizowane w ostatnich latach lokomotywy elektryczne i spalinowe $w$ Polsce, Technika Transportu Szynowego, $n r$ 4/2011.

[6.] Marciniak Z.: Analiza oferty producentów krajowych w zakresie nowego i modernizowanego kolejowego taboru trakcyjnego. Materiaty seminarium „Najnowsze regulacje prawne $w$ zakresie interoperacyjności i bezpieczeństwa $w$ budowie, modernizacji i eksploatacji taboru kolejowego", Warszawa, 10.2012.

[7.] Marciniak Z., Jakuszko W., Michalak P.: Nowe uklady $i$ rozwiazania techniczne $w$ modernizowanej lokomotywie spalinowej serii SM42 typu 6Di, Pojazdy Szynowe, $n r$ $1 / 2013$.

[8.] Terczyński P.: Lokomotywy E186 i E189 w Polsce, Świat Kolei, $n r$ 4/2012.

[9.] Katalog lokomotiv a speciălnich vozidel. Wydawnictwo CZ LOKO, a.s. Czeskă Třebova, 2012.

[10.] Nowe lokomotywy, Vossloh Locomotives. Rodzina nowych lokomotyw z przektadniami elektrycznymi i hydraulicznymi o mocy 1200 do $1800 \mathrm{~kW}$. Materiaty seminarium: ,Wymagania w zakresie standaryzacji, bezpieczeństwa, eksploatacji i utrzymania oraz efektywności inwestycji dla nowego $i$ modernizowanego taboru kolejowego", Warszawa, 03.2011.

[11.] Platforma lokomotyw. Gama Marathon, Materiaty reklamowe firmy PESA Bydgoszcz, 2012.

[12.] Electric universal locomotive. Vectron, Materiaty reklamowe firmy Siemens AG 2012.

[13.] Konstrukcje modulowe tworza przyszłość The future is modular, Materiaty reklamowe firmy Vossloh Locomotives $\mathrm{GmbH}$.

[14.] Platforma lokomotyw czteroosiowych Griffin. Nowoczesne rozwiazania dla transportu kolejowego Materiaty reklamowe firmy Newag - Gliwice. 